Journal of Business School

2021, 4(3): 197-219

DOI: $10.26677 / T R 1010.2021 .904$

Journal Homepage: https://www.journalbusiness.org

\title{
What is the Optimal Tax Treatment That Motivates Donor Corporations to Make More Monetary and in-Kind Donations to Their Communities and With Minimal Damage to The Interests of All The Parties Involved, and The Content of The CSR Idea?
}

\author{
Younis A. Battal Saleh \\ B.Sc.-M.Sc.-CPA-CEA in Accounting \\ Lecturer and Researcher \\ battalsaleh@yahoo.com \\ https://orcid.org/0000-0002-4209-3132
}

\begin{abstract}
This theoretical study attempted to answer the following question: What is the optimal tax treatment that motivates donor corporations to make more monetary and in-kind donations to their communities and with minimal damage to the interests of all the parties involved, and the content of the CSR idea? To answer this complex question, the researcher was forced to imagine all possible tax treatment methods for corporate monetary and in-kind donations and to determine their advantages and disadvantages -according to certain criteria, to choose the optimal tax treatment method. This study recommends the adoption of the method of government's rights and then corporation's rights in government's rights "donations as if they are loans" by legislative bodies in all countries of the world due to the abundance of its advantages. This method is optimal. This method will motivate donor corporations to make more monetary and in-kind donations to their communities and with minimal damage to the interests of all the parties involved, and the content of the CSR idea.Given the importance of this method. This study has drawn up a draft law for this method, which could be used as a guide by the legislative bodies, if adecision is made to adopt this method.
\end{abstract}

Keywords: Corporate Philanthropy. Corporate Social Responsibility (CSR). Corporate Donations .Tax Treatment. Tax Incentives. Advantages and Disadvantages. Legal Imbalances. Economic Impacts.

\section{INTRODUCTION}

Usually, the tax treatment of corporate monetary and in-kind donations-in any country, stems primarily from the law- makers' view about corporate philanthropy" their interpretation and understanding of the meaning "What do donations mean to them? ". Through this interpretation and understanding, they can determine tax treatment that fits their seeing and perception of monetary and in-kind donations provided by donor corporations. Such treatment is often associated with a reduction in taxable income. This is the usual treatment in most countries of the world. It definitely will not be the only treatment. Those donations can also be addressed through a reduction in the value of the income tax or a complete disregard for such contributions when determining income tax. According to the researcher, the perceptions about understanding the meaning of corporate donations (interpretation of the meaning "What do donations mean? ") 
cannot exceed one of the following five scenarios: Donations as if they are operating expenses or donations as if they are indirect taxes or donations as if they are not granted or donations as if they are loans or donations as if they are joint cost. Based on this perception, by using new distinctive terms and idioms, possible methods for the tax treatment of corporate donations can be classified into five main methods:(1) Method of" society's rights" donations" and then government's rights" income tax " (tax exemption in the sense of deduction "the deduction is made on taxable income" ). Donations as if they are operating expenses; (2) Method of" society's rights and then government's rights (tax exemption in the sense of restoration "the deduction is made on income tax"). Donations as if they are indirect taxes"; (3) Method of "government's rights and then society's rights". Donations as if they are not granted"'the deduction is made on taxable income" ; (4) Method of government's rights and then Corporation's rights "part of the donation value (installment)" in government's rights. Donations as if they are loans" "the deduction is made on income tax" [Saleh, p.75]; (5) Method of" government's rights and then part of society's rights in government's rights. "Donations are joint cost: as an investment in competitive advantage "or for other purposes unknown and unspecified, motivated by humanitarian, or religious, or patriotism, etc." and a cost that contributes to achieving the social benefits ". Part of the cost is an investment in competitive advantage. This part should be excluded from the calculation "arithmetic operation". And the other part of the cost contributes to achieving the social benefits. This part can be considered indirect taxes, and therefore this part must be deducted from income tax "government's rights" (tax exemption in the sense of restoration), or considering it necessary operating expenses according to the concept of the idea of the social contract, (tax exemption in the sense of deduction "which must be deducted from the taxable income"). The prevailing economic conditions in society may directly affect the identification and selection of tax treatment that is appropriate to these circumstances.

\section{HIGHLIGHTING THE PROBLEM}

The tax treatment that allows the granting of tax incentives to donor corporations is not optimal" because it suffers from many distortions." According to the following justifications: 1) This method distorts the content of the idea of CSR; 2) This method suffers from legal imbalances; 3 ) This method creates undesirable economic effects. And in light of the perception that there is a package of alternative tax treatments, "what is the optimal tax treatment that motivates donor corporations to make more monetary and in-kind donations to their communities and with minimal damage to the interests of all the parties involved, and the content of the CSR idea?" That tax treatment that will not be accompanied by any unwanted distortions, and that will contribute to the improvement of corporate income tax laws.

\section{Logical interpretation of the phrase "Corporate donations are a joint cost"}

In the modern era, in developed countries that are now more open to the global economy, and in light of full competition "at the local and international level," the competitive advantage has become one of the most important requirements affecting the survival, continuity and growth of corporations in the economic, social and political environment in which they operate.The commitment of corporations to their social responsibility is one of the pillars and ingredients that contribute to creating a competitive advantage. The philanthropic responsibility "interacting with societies' issues and aspirations through a monetary and in-kind donation" is considered one of the responsibilities of the corporation, which directly and significantly contributes to creating a competitive advantage. One of the explanations that the researcher provided in this study is to consider corporate donations as a joint cost. According to the researcher's perception, corporate donations are an investment in the competitive advantage that results in achieving social benefits for society or one of its sects- at the same time. Donations contribute to achieving two purposes: "competitive advantage "or for other purposes unknown and unspecified"; and social benefits." 
Therefore, it can be considered as a joint cost that contributes to creating and enhancing the competitive advantage "intangible asset" and the production of social benefits to other parties in society, regardless of the impact of the total donation value on the amount of social benefits or on the growth and strengthening of the mass of the competitive advantage of the corporation. The process of separating the costs "donations" to distribute them on the competitive advantage and social benefits achieved is very difficult. The part that relates to social benefits can be considered indirect taxes (especially if the donations are in the areas of government spending)," amounts paid to the public interest without mediating the tax authority in the process of receiving and re-spending", or considering it necessary operating expenses according to the concept of the idea of the social contract.

If the donations are considered operating expenses, this can be justified as follows: Although donations are voluntary, non-compulsory, they are in the modern era and in the world of competition are necessary for survival, continuity and growth within the mass of competitors. Donations are necessary to create the competitive advantage that ensures the continuation and growth of corporations. For this reason, these donations may be seen as operating expenses that are no less important than other expenses in generating income and improving the economic performance of corporations." The corporation provides donations to its society-in which it operates, as compensation for the depletion of its resources and damage to its environment, as a result of the corporation's practice of its economic activity. Without this price, the economic performance of that corporation will be negatively affected. Bills for the purchase of raw materials, salaries and wages paid for workers' effort, and expenditures for environmental restoration are considered incomplete without that price "Donations." According to the social contract theory, the value of bills for purchasing raw materials and services from the community in which the corporation operates, and the value of workers 'paychecks are not real. They are much less than their real values. And the complementary value of those values (added value to those values to bring justice to society) is what corporations make as donations to their societies. Operating expenses are the sacrifice that corporations must make for survival, continuity and growth. Operating expenses contribute to achieving the profit, and donations are to enhance the competitive advantage that ensures the continued economic growth of these corporations. Donations like all other expenses, they contribute to achieving the profit "economic growth", but indirectly. Hence, donations can be considered operating expenses that are no less important than the rest of the other operating expenses, especially in light of full competition and in the presence of the consumer and investor most aware of the importance of the role of CSR. In light of full competition and corporations' reliance on a competitive advantage in achieving their economic goals, corporations will not stop making donations. Making more donations depends on the tax benefits and incentives granted and permitted by laws and regulations in the country.

Corporate donations can be seen from several angles. Each angle represents a particular perception. These visions are derived from how to interpret the meaning of those donations by legislative bodies, depending on the analysis of the effects that such donations can produce. Donations can be envisioned as if they are operating expenses. The idea of this perception stems from the following justification: In the modern era, donations contribute indirectly to improving the economic performance of corporations by gaining the loyalty and satisfaction of employees, consumers, investors and community- especially in communities that recognize the importance of CSR. In contemporary societies, such expenditures (voluntary contributions) are becoming increasingly necessary without them those corporations will not be able to enhance their position in the markets of these communities" as one of the requirements of competitive advantage acquisition". As well as, according to the content of the social contract theory "this contract implies some indirect obligations of business towards society."The annual invoices value paid by 
corporations for the purchase of materials, goods and services, and the annual values paid in exchange for purchasing the human effort" salaries and wages" are incomplete. They are much less than their real value. Annual donations made by corporations to their societies are to supplement the paid values "the incomplete values" in exchange for depleting their resources and harming their environments, in order to reach the real values of those materials, goods, services and the human effort gained from those societies. On this, it can be said that the corporate annual donations are operating expenses. Donations can be envisioned as if they are indirect taxes. The idea of this perception stems from the following justification: The government uses the money earned from corporate taxes to finance public sector expenditures in order to provide services to its citizens, as well as to finance various development programs. Donations made by corporations also contribute to promoting economic and social development in the communities in which they operate, and solving many social issues of certain communities in those societies. These donations have a positive impact in field of the service of the common good. Therefore, donations can be considered as indirect taxes provided by corporations to their communities without mediation the government in the process of receiving and re-spending. Ignoring these expenditures may create a state of double taxation. Donations can be envisioned as if they are not granted. The idea of this perception stems from the following justifications: Donations are expenditures that have nothing to do with the economic activity of corporations. In other words, they do not contribute directly to achieving the profit and their impact on the corporation's economic performance is unclear. Donations are voluntary activities "charitable acts" that should be completely ignored when determining taxable income. Not to ignore these expenditures will contribute to harming the government by reducing its tax revenues. CSR does not mean giving benefit to a party at the expense of another. CSR means achieving justice among all stakeholders. As is known, donations are often given to non-profit organizations or charities, with the aim of providing assistance to specific communities or to addressing special issues. In this case they are not to support the vital expenditures of the government. When donations are made to nonprofit organizations or charities, the claim that these donations should be ignored will be justified. Those charitable acts - in these areas, must be borne by donor corporations and not the government "by reducing its tax revenue." Equitable rights must be achieved among the donor corporation, the government, and the beneficiaries of such donations. The interest of the donor corporation and the beneficiaries of the donation should not be at the expense of the government "at the expense of government revenue." As a result of these contributions, the corporation may gain the tax savings resulting from those contributions and government will bear the burden of the decline in the volume of its revenue from taxes, so this result will be considered unfair to the government. As well as, Donations may be the entrance to pass many unethical practices and behaviors. This vision may be acceptable in the case of monopolistic corporations and noncompetitive markets." As there is no indirect positive impact of those expenditures on the profitability of the corporation." Also, this vision can be accepted in the most corrupt societies. Another argument to support this vision, corporate donations can be considered are alms made by shareholders or owners paid from their ownership rights in the corporation. Donations, according to this vision are nothing more than a reduction in the value of ownership rights. The deduction of donation values from shareholders 'equity reflects corporations' pure commitment to their CSR. Donations can be likened to withdrawals from invested capital for personal purposes that have no effect on the results of the corporation's activity. Donations can be envisioned as if they are loans "interest-free loans." The idea of this perception stems from the following justifications: CSR does not mean giving priority to philanthropic responsibility over economic responsibility. Rather, the two responsibilities must be adhered to in a more harmonious manner. The idea of corporate donations as if they are loans is to create real harmony between corporate economic responsibility" protecting the corporation's economic capabilities" 
and corporate philanthropic responsibility" providing social benefits by moving from a waiver approach to a lending approach ". Government spending is for the purpose of achieving wellbeing in all areas for citizens- it is the responsibility of the government. Taxes represent government rights in corporate profits. Any obligations paid by the corporation on behalf of the government must be returned to corporation by reducing the value of taxes due to the government. The non-return of these contributions to donor corporations means covering up the government's failure to manage its affairs, including the search for financial resources other than taxes (corporate donations may contribute to the emergence of a surplus in the state budget. This surplus does not reflect the effectiveness and efficiency of the government in the management of state affairs.). Spending on public sectors and government bodies, addressing social issues and strengthening the infrastructure of the state is the competence of the government, it is not the competence of corporations.

If corporations do not make donations, then governments will resort to borrowing. Donations are voluntary, not compulsory. They are mostly to finance what the government is unable to finance or to finance projects and programs that serve the public interest and that are not included in the government's plan at the present time. Of course, those programs and projects, if the government wants to implement them in the current period, it would have to borrow to finance them. Regardless of any other considerations, for this reason, corporate donations can be considered as indirect loans to support the government. The intended meaning of this perception lies in tax treatment and not in the acceptance or non-acceptance of such donations by the government. Donations can be envisioned as if they are joint cost. One of the visions that the researcher provided in this study is to consider corporate donations as a joint cost. According to the researcher's perception, corporate donations are an investment in the competitive advantage( as an intangible asset)"or for other purposes unknown and unspecified " motivated by humanitarian, religious, or patriotism ,etc. ", that result in achieving social benefits for society or one of its sects- at the same time. Donations contribute to achieving two purposes, "competitive advantage and social benefits." The process of separating the costs "donations" to distribute them on the competitive advantage and social benefits achieved is very difficult. When determining tax exemption in exchange for these donations" for these donations", the part that relates to competitive advantage is an investment "intangible asset" that must be excluded, while the part that relates to social benefits can be considered indirect taxes (especially if the donations are in the areas of government spending), " amounts paid to the public interest without mediating the tax authority in the process of receiving and re-spending" ( tax exemption in the sense of restoration), or considering it necessary operating expenses according to the concept of the idea of the social contract "(tax exemption in the sense of deduction)."

Based on these visions and perceptions, the researcher identifies all tax treatment methods that cannot exceed the following five methods: Method of society's rights and then government's rights (tax exemption in the sense of deduction)" donations as if they are operating expenses ;Method of society's rights and then government's rights (tax exemption in the sense of restoration "return") donations as if they are indirect taxes"; Method of government's rights and then society's rights" donations as if they are not granted"; Method of government's rights and then corporation's rights in government's rights" donations as if they are loans.";Method of" government's rights and then part of society's rights in government's rights, "donations are joint cost: as an investment in competitive advantage and achieving social benefits ", and a part of donations as if it is indirect taxes( tax exemption in the sense of restoration), or considering it necessary operating expenses according to the concept of the idea of the social contract, (tax exemption in the sense of deduction). 
The most used method in most countries of the world is the tax treatment that allows a portion of corporate donations to be deducted from taxable income. -with the difference in discount rates adopted in those countries." According to the perception of donations as if they are a joint cost." This method motivates corporations to make donations because it allows tax incentives to be granted to donor corporations. The questions posed by the researcher, is this law or tax treatment optimal or not? In other words, does this method contribute to the promotion of economic development and infrastructure in the country? Does this method suffer from legal imbalances? Is this method in tune with the content of CSR idea? These questions can only be answered after evaluating all the methods that are expected to be used and that can be used (or actually used) for the tax treatment of corporate donations by studying their economic effects, legal imbalances and their impact on the content of the idea of CSR. And to this end, there is an idea .That idea is to visualize all the methods that are expected to be used and that can be used (or actually used) for the tax treatment of corporate donations that could be used in comparison processes. Here, the following question can be raised, what criteria can be used in the comparison process? The problem raised by this theoretical study in this part lies in the following questions: What are the legal imbalances associated with the tax treatment methods of corporate donations? What are unethical practices can be passed through these methods? What are the economic effects that these methods can produce? Do specialized legislative bodies in the field of issuing corporate income tax laws take into account the impact of tax treatment of corporate monetary and in-kind donations on the real content of the idea of CSR when making laws or not? In other words, are the laws issued by legislative bodies "enacted legislation in the area of tax treatment for donations" in line with the content of the CSR idea? How can this be explained" compatibility between tax treatment methods and the content of the idea of CSR? Do the laws aim to encourage corporations to incur such expenditures without taking into account the content of the CSR idea or are they to consolidate the CSR's high principles such as achieving justice in rights, combating of immoral behaviors and the rejection of opportunism, etc.? Where all tax treatment methods have an impact on the core of CSR idea, but with an interpretation and philosophy differ from one method to another. The specialized legislative bodies in the field of issuing corporate income tax laws in all countries of the world must be aware" must be fully informed" of the impact of laws "enacted legislation in the field of tax treatment of corporate monetary and in-kind donations" on the content of the CSR idea. To achieve this, these bodies can rely on the content of the controversy that will be raised by the researcher in this study.

\section{Objectives of the study}

The objectives of this theoretical study can be defined in the following points:

(1) Identification of potential" possible" methods that can be used for tax treatment of corporate monetary and in-kind donations; (2) Defining the advantages and disadvantages "positive and negative effects" of the methods of tax treatment for corporate donations. In other words, to identify the legal imbalances, the economic effects resulting from these methods and the extent of the harmony of these methods with the content of the idea of corporate social responsibility; (3) Determining the optimal method according to legal and economic considerations, that optimal method that can also safeguard the content of the idea of CSR and develop it.

\section{The importance of studying}

This study will open new horizons for evaluating and developing tax treatment methods for corporate donations and more scientific research opportunities in this field. 


\section{Materials and methods}

In order to determine the advantages and disadvantages of tax treatment methods for corporate donations and make comparisons for the purpose of determining the optimal tax treatment-Its advantages are more than its disadvantages, this study identified three reasonable criteria that can be used in evaluating tax treatment methods and making comparisons. Those criteria are: Economic impact; Legal imbalances; The extent of closeness to, or distance from the content of the idea of CSR

\section{LITERATURE REVIEW}

\section{The Corporate Social Responsibility (CSR)}

The idea of CSR is nothing new. The new is the evolution that has occurred in the content of its thought over time. CSR - which means the need to conduct business in a socially responsible manner, evolved from an era of philanthropic initiatives to an era of strategies and policies that meet the needs and ambitions of the communities in which they operate.CSR was no more than philanthropic initiatives by employers to help workers and the poor. Improving working conditions, consumer protection and welfare, environment protection, interacting with community issues and aspirations, compliance with all sustainable development requirements represents the recent salient developments in CSR thought.

The charity provided by the employers to the poor and their employees in the past centuries has had a great impact on the emergence of CSR thought. Among the general public, there is still confusion between the concept of philanthropic responsibility and CSR. The first is considered one of the components of the second. It contributed to its development. Development does not only include the concept of CSR, but also encompassed the concept of philanthropy - as one of its components, to transform from a mere practice into an effective strategy.

There are many definitions of CSR with similar meanings. In this study, the researcher has developed a definition that includes almost all those meanings. The researcher defines CSR in its general sense as follows: Corporate Social Responsibility (CSR) means exercising economic activities (by corporations) with legal guidance and ethical behavior, when achieving their desired goals that ensure the growth and continuity for them. Taking into account compliance with the following requirements: Contributing to the continuation of life and improving its quality, and achieving prosperity on the planet Earth for present and future generations; Not to inflict material and moral damage on others, and serious interaction with them to achieve common interests, and belief that they are a important and irreplaceable part to ensure the process of their continuation and achievement of their objectives; Commitment to everything that makes life organized in the environment in which they work.

\section{Corporate Philanthropic Responsibilities}

The philanthropic responsibilities are the voluntary responsibilities of the enterprise. They reflect the current expectations of the public towards the enterprise. These volunteering activities are animated only by the desire of the enterprise to involve itself in community activities which are not imposed or requested by law and which generally are not to be expected from an enterprise, in an ethical way. The public expects that an enterprise should involve in philanthropic actions and thus this category becomes a part of the social agreement between the enterprise and the society. Such activities can include donations of goods and services, volunteering activity, the involvement of the enterprise or of its employees in the community or of the stakeholders. Philanthropy includes those corporate actions which answer to the society's expectations, according to which the enterprises are good corporate citizens. This includes the efficient commitment in actions or programs of promoting the welfare or the human good will [Grigore, 
p. 170; Carroll, p. 4]. The researcher defines philanthropic responsibility as a component of CSR as follows: It is a set of the initiatives that includes philanthropic "material and non-material donations" that contribute to improving the quality of life within the communities in which they operate, which is voluntarily provided by corporations without any legal coercion, in response to the aspirations of contemporary societies and their urgent desires to develop the role of corporations to be the ideal partner who will bear part of their worries and problems due to the inability of governments - in most countries of the world, to meet all the needs of their contemporary societies and achieve all their aspirations.

\section{Population explosion and increasing government burdens}

In modern times, and in light of the population explosion in most countries of the world, and the scarcity of economic resources and the growing burden of the government in the face of contemporary challenges, foremost of which are to achieve the economic well-being of their communities, improve the standard of living of their citizens, and enhance the security and integrity of their lands. Governments are no longer able to finance all development projects, strengthen infrastructure, meet contemporary challenges, meet the aspirations of their people at the same time, and with the same economic resources available. It was necessary to have a reliable partner, which could contribute to shoulder part of the burden of those governments. That partner is the private sector" corporations ", by adhering to its social responsibility towards the community in which it operates, as a compensation for the depletion of its economic resources and the damage to its material and moral components by that sector in order to achieve its economic gains. Therefore, both corporations and governments should contribute to the achieving well-being and improving the quality of life of their communities. No one can achieve this alone.

\section{Corporate Philanthropy" Corporate Giving / Corporate Donation"}

Philanthropy is a term connected with the American tradition of charitable giving. At first it was associated with a person- philanthropist, but today the term corporate philanthropy is more developed, meaning business sector's voluntary giving [Mihaljevic and Tokic, p. 804]. Philanthropy stems from the Greek word which means love of humanity. Popular interpretations today refer to private initiatives for public good (J. W. Gardner) or initiatives directed at the improvement in the quality of human life (Robert Bremner). Colloquially, philanthropy is most commonly used interchangeably with charitable giving. - WINGS [John et al, p.136]. Corporate philanthropy is the act of corporations donating a portion of their profits or resources to various non-profit organizations [Madrakhimova, p.125]. This definition may be consistent with the laws in some countries that require the payment of donations to nonprofit organizations to prevent fraud and deception. This definition is limited, it excludes direct donations to poor people, completion of some public projects such as building schools and hospitals, etc. as well as nonmaterial help for the public good" volunteer work ", unless the laws of the State so require, where the public interest so requires. Here, nonprofits will play the role of mediator. Another definition is: The use of discretionary financial and human resources for primarily public benefit, while recognizing that impact might also accrue for the company's shareholders and employees [John et al, p.133].The researcher defines corporate philanthropy (corporategivingor corporatedonation) as follows: It is all material donations" money, assets and goods" and nonmaterial "services ", which are provided to nonprofit organizations or the poor and the needy or for the public good to improve the quality of life in the community. This may result in the achievement benefits for corporations such as exemptions and tax incentives, in addition to enhancing the competitive advantage. There is increasing interest by corporations in their philanthropic responsibility, especially in developed countries, where many studies have shown that corporate giving has been on the rise in recent years. For example, a study on corporate 
donations in the United States in 2005 has shown that 62 biggest companies in the U.S. gave $\$ 8.4$ billion last year, an increase of $14 \%$ from 2004. Also, $87 \%$ of the companies surveyed indicated that they have an employee volunteer program, with $44 \%$ of them offering paid time off to employees who volunteer [Man, p.1; Perry].The global survey of CSR spending over the period 2011 - 2013 by Dattani et al. (2015) revealed that the top 10 most generous companies worldwide gave US\$ 17.7 trillion towards CSR spending annually. An estimated 28 percent of this sum (nearly US\$5 trillion) was in the form of grants rather than in-kind donations or volunteering [John et al, p.18].Donations may be a stone for more than a bird "more than a purpose."They may hide behind them many unwanted behaviors, in addition to legitimate purposes. The purpose of the donation depends on the intentions of the donor.In general, donations can be a tool to achieve the following purposes: Embezzlement "collusive embezzlement"; Tax evasion; Political gains; Tax incentives; Competitive advantage; Improving the quality of life; Distracting the attention of the public opinion on a particular issue; To reduce or avoid losses resulting from obsolescence or expiration of inventory [Saleh, p.89-93].

Income tax is a key source of funds that the government uses to fund its activities and serve the public.Those funds of the taxes are part of the revenues of the state government, without those funds the government cannot manage the state affairs.Corporations must be committed to supply" pay" the value of taxes to the tax administration"tax authority." That commitment comes from the reality of the legal responsibility of corporations to the community and its institutions.Also, non-compliance with tax laws and tax evasion by corporations meanfacing sanctions in accordance with the law of the State's economic crimes." Academics have advocated including the paying of taxes in CSR. For example, the American professor Avi-Yonah adamantly maintains that companies bear a social responsibility that includes loyally paying taxes.He also argues in favor of companies refraining from business transactions whose sole objective is to minimize taxes" [Avi-Yonah; Svernlöv, p.8].On the contrary, in recent years, there have been calls for the development of tax laws on corporate income in many countries of the world. This calls for the need to change the Laws to conform to the strengthening requirements of the idea of practice of CSR by corporations through the creation of a system of incentives to achieve tax justice among the corporations and contributes to encouraging corporations to adopt the idea of social responsibility. For example, Jordanian Al Rai newspaper published an article on 18 - 11- 2014 under the title" The private sector calls for legislation to stimulate the adoption of the idea of CSR."Also, there were some actual initiatives in many countries aimed at reforming tax systems, for example, tax reform in France in 2003about incentives for corporate giving \ corporate philanthropy [Lordemus, p. 16].The Sudaress website published an article in 2013 under the title "Donations for Taxes". This article was an invitation to the Sudanese government to develop the tax code to encourage taxpayers to donate as is the case in the United States. This article stressed the need to find a law that allows deducting the contributions of corporations and businessmen from the taxes imposed on them [Sudaress].In order to encourage taxpayers to contribute to charity and community service. In 2017, the Sultanate of Oman carried out tax reforms "Amendment to the Tax Code" under Royal Decree No. 9/2017.Those reforms included tax treatment of donations.In kind donations are as costs that must be deducted when determining taxable income. Those amendments were as incentives for donors [Ministry of Finance].

\section{RESULTS}

The tax treatment of corporate donations emanating from the perception of "donations as if they are loans" is considered the best, given the many advantages of it. It can contribute to achieving the following: Motivating donor corporations to make more donations; Creating true harmony between corporate economic responsibility and corporate philanthropic responsibility; 
Developing the concept of corporate philanthropic responsibility by moving from a donation approach to a lending approach; It is consistent with the content of the CSR idea; According to the perception of this study - regarding this method, it will contribute to achieving real economic development and strengthening the infrastructure in the country; It will reinforce the concept of social solidarity within the community "the development of contemporary societies is a collective responsibility."

\section{CONTENT OF THE IDEA OF CSR:}

The idea of CSR includes many lofty principles, including but not limited to the following: The fight against all forms of corruption, fraudulent practices and unethical behaviors such as tax evasion, deception and fraudulence "pay with your right hand and take with your left hand."Achieving justice in rights among all stakeholders. CSR means promoting freedoms and rights, supporting human and economic development, and contributing to improving the standard of living, economic well-being and infrastructure development in societies.The corporations ' purpose of the commitment to social responsibility should be to enhance their competitive advantage by gaining the satisfaction and loyalty of society and government, consumers, investors, etc. .Corporations take their resources from the communities in which they operate, and often those communities are affected by the damage produced by those corporations.Corporations will be obliged to compensate those communities. Donations and loans are part of that compensation.It is not within the content of the idea of CSR to gain economic benefits out of the scope of the competitive advantage. If this problem "defect" occurs, the CSR will lose its meaning and lofty principles.

\section{TAX TREATMENT METHODS OF CORPORATE MONETARY AND IN-KIND DONATIONS}

Tax treatment methods for corporate donations in all countries of the world cannot exceed one of the following scenarios: (1) Method of society's rights and then government's rights (tax exemption in the sense of deduction" the deduction is made on taxable income"). Donations as if they are operating expenses;(2)Method of society's rights and then government's rights (Tax exemption in the sense of restoration "return" "the deduction is made on income tax"). Donations as if they are indirect taxes"; (3) Method of government's rights and then society's rights. Donations as if they are not granted ; (4) Method of government's rights and then corporation's rights in government's rights. Donations as if they are loans[Saleh,p.95];(5) Method of" government's rights and then part of society's rights in government's rights,( Tax exemption in the sense of restoration) or Method of a part of society's rights and then government's rights (Tax exemption in the sense of deduction)."Donations are joint cost "as an investment in competitive advantage "or for other purposes unknown and unspecified," and achieving social benefits ", A part of donations as if it is indirect taxes (Tax exemption in the sense of restoration), or this part as if it is operating expense (Tax exemption in the sense of deduction).

There is a real harmony between the expected visions of corporate donations and the tax treatment methods derived from those visions. Donations as if they are operating expenses (donations are deducted from taxable income). Donations as if they are indirect taxes (donations are deducted from income tax). Donations as if they are not granted (donations are completely ignored). Donations as if they are loans (the total value of donations is deducted from income tax in annual installments). Donations as if they are joint cost: A part of the donations is deducted from the taxable income or a part of the donations is deducted from the income tax. 


\section{DONATIONS AS IF THEY ARE OPERATING EXPENSES}

Method of society's rights and then government's rights (Tax exemption in the sense of deduction). This method may be used as a tool to motivate corporations to make more and more donations. According to this method, corporate monetary and in-kind donations are considered as expenditures" operating expenses" which must be deducted from revenues. This method allows deducting the value of monetary and in-kind donations from the value of revenue to determine the value of taxable income and the value of the tax invoice. To calculate income tax: Revenue $-($ Operating Expenses + Donations $)=$ Taxable Income X Income Tax Rate $=$ Income Tax. Or Revenue - (Operating Expenses + Society's Rights) $=$ Taxable Income X Income Tax Rate $=$ Income Tax" Government's Rights."

\section{DONATIONS AS IF THEY ARE INDIRECT TAXES}

Method of society's rights and then government's rights (Tax exemption in the sense of restoration). In this method, the exemption is in the sense of restoration "return" and not the in the sense of deduction" reduction." This method is similar to the previous method and the difference between the two methods lies in the interpretation of the meaning of tax exemption. For this method, corporate monetary and in-kind donations are considered as indirect taxes that must be returned to the donor corporation by reducing the value of the tax invoice by the value of those donations- to avoid double taxation. According to this method, community rights" value of donations " must be deducted from the value of the income tax" government's rights ", what remains of the value of that invoice will be considered as the rights of the government. To Calculate Income Tax: Revenue- Operating Expenses $=$ Taxable Income X Income Tax Rate $=$ Income Tax- Donations=The Final Value Of The Tax Invoice.

\section{DONATIONS AS IF THEY ARE NOT GRANTED}

Method of government's rights and then society's rights. According to the principle of nonconfusion "non-mixing" between the rights of stakeholders "government and society." This method pays no attention to monetary and in-kind donations, and it does not grant any tax exemptions. Where taxable income and income tax would be calculated without taking into account such donations. To calculate income tax: Revenue - Operating Expenses $=$ Taxable Income $X$ Income Tax Rate $=$ Income Tax. (Taxable Income- (Income Tax+ Donations)=Shareholders' Equity Or Distributable Income".

\section{DONATIONS AS IF THEY ARE LOANS}

Method of government's rights and then corporation's rights in government's rights. This method is very similar to the method of society's rights and then government's rights (tax exemption in the sense of restoration), however, the difference between the two methods lies in the interpretation of the meaning of the donation. Also, how to return donations to donor corporations.(how to return donations to donor corporations). According to this method, donations must be made by corporations in the areas of government spending. Donations must be returned in full to the donor corporations in installments that must be deducted from annual income taxes of donor corporations. Donations, according to this method, can be considered as loans to support the government that must be returned to the donor corporations in batches" in installments." To calculate income tax: Revenue- Operating Expenses $=$ Taxable Income X Income Tax Rate = Income Tax- A Part Of The Donations" Annual Installment"= The Value Of The Final Invoice For The Annual Income Tax. 


\section{DONATIONS AS IF THEY ARE JOINT COST}

Method of "government's rights and then part of society's rights in government's rights. A part of the donations as if it is indirect tax (tax exemption in the sense of restoration), or Method of a part of society's rights and then government's rights. A part of donations as if it is operating expense (Tax exemption in the sense of deduction). Corporate donations are an investment in the competitive advantage (as an intangible asset)" or for other purposes unknown and unspecified "motivated by humanitarian, religious, or patriotism, etc." to the legislative body," that results in achieving social benefits for society or one of its sects- at the same time. Donations contribute to achieving two purposes "competitive advantage and social benefits." Therefore, they can be considered as a joint cost that contributes to creating and enhancing the competitive advantage and the production of social benefits to other parties in society, regardless of the impact of the total donation value on the amount of social benefits or on the growth and strengthening of the mass of the competitive advantage of the corporation. When determining tax exemption in exchange for these donations, the part that relates to competitive advantage is an investment that must be excluded, while the part that relates to social benefits can be considered indirect taxes (especially if the donations are in the areas of government spending), " amounts paid to the public interest without mediating the tax authority in the process of receiving and re-spending". To calculate income tax : Revenue - Operating Expenses =Taxable Income X Income Tax Rate = Income Tax- A Part Of The Donations" Share Of Social Benefits From The Joint Cost" = The Value Of The Final Invoice For The Annual Income Tax(Tax Exemption In The Sense Of Restoration).Or considering it necessary operating expenses according to the concept of the idea of the social contract, (tax exemption in the sense of deduction).Revenue - ( Operating Expenses+ A Part Of The Donations" Share Of Social Benefits From The Joint Cost") = Taxable Income X Income Tax Rate $=$ Income Tax. A Part Of Donations As If It Is Operating Expenses (Tax Exemption In The Sense Of Deduction).

\section{TAX EXEMPTION, TAX SAVING AND THE REAL SACRIFICE}

Tax exemption means reducing the value of the tax invoice, either by reducing the value of taxable income or by reducing the value of the income tax. There is a difference between tax exemption in the sense of reduction and tax exemption in the sense of restoration. In the first status: Exemption means reducing taxable income by the value of donations "or a part of it." In the second status: Exemption means the reduction of the value of the tax invoice "income tax" at the value of such donations or part thereof." Both "reduction and restoration" contribute to the reduction of the value of the tax invoice payable.

\section{Tax Saving and the Real Sacrifice}

Tax saving resulting from donations can be defined as follows: It is the amount of the decrease in the value of the income tax paid by the corporation to the fiscal administration on a definite financial period as a result of incurring monetary and in-kind donations during that period. The Real Sacrifice is the difference between the value of monetary and in-kind donations and the value of tax savings. The Real Sacrifice $=$ The Monetary And In-Kind Donations - Tax Savings. Tax exemptions result in what is known as a compulsory partnership between the government and the corporation in financing the donations made to their beneficiaries. The tax saving earned by the donor corporation is the sacrifice that the government makes as an incentive for that corporation, and it represents a decrease in the value of its tax revenues. 


\section{ADVANTAGES AND DISADVANTAGES OF THE FIVE METHODS OF TAX TREATMENT OF CORPORATE MONETARY AND IN-KIND DONATIONS}

All previous methods have advantages and disadvantages, but to varying degrees. To adopt one of these methods to be used in the treatment of monetary and in-kind donations in any country depends on philosophy of the legislative body about donations, and the extent of its understanding of the depth of the idea of CSR, taking into consideration the prevailing economic conditions in the state.

\section{Evaluation and comparison criteria}

To determine the advantages and disadvantages of tax treatment methods, one must first find a set of logical criteria. These criteria will be used to infer "conclude" the advantages and disadvantages of those methods. The researcher has identified three criteria that can be used in comparison operations for evaluation purposes and for extracting advantages and disadvantages of those methods. Those criteria are:

\section{Economic Impact}

This criterion refers to the extent to which the tax treatment method of corporate donations contributes to the promotion of economic development and infrastructure development in the country in an effective manner. As well as a statement of the positive or negative impact on government revenues from taxes, the market value of the shares of the donor corporations and shareholders' equity.

\section{Legal Imbalances}

This criterion refers to the legal imbalances that can be produced by the tax treatment method of corporate donations such as double taxation, failure to achieve tax justice among corporations and failure to achieve justice in rights among all stakeholders affected by such treatment "government, society, investors, etc."

\section{The Extent of Closeness to, or Distance from the Content of the Idea of CSR}

This criterion refers to the extent of harmony between the tax treatment method of corporate monetary and in-kind donations and the content of the idea of CSR and its supreme principles. In other words, the contribution of the method of tax treatment in reducing or preventing the phenomenon of tax evasion, the practice of unethical behavior, and opportunistic behavior by corporations. As well as, achieving justice in rights.

The idea of CSR has come into existence in order to create a greater role for corporations in their communities, and fruitful interaction between those corporations and their communities in which they operate. Those communities, through which such corporations obtain their economic resources, market their products, on the other hand, those corporations are exporting their damages to those communities. That role that transcends the barriers of their traditional role of maximizing profits and gains. This does not mean that corporations will not achieve any economic benefits by adhering to their social responsibility, on the contrary, corporations can achieve economic benefits by adhering to their social responsibility, but the only way to reach that goal is through gaining the competitive advantage, which can be created by that commitment. Competitive advantage can be achieved through the loyalty and satisfaction of employees, consumers, society, government and investors. That loyalty and satisfaction can be gained through a corporate commitment to their social responsibility; CSR means not waiting for any economic benefits, except for those benefits that are achieved by competitive advantage ;CSR means devotion, the sincerity of the intentions, and great loyalty in commitment, not pretending the commitment for misleading propaganda purposes in accordance with the policy of giving 
with the right hand and taking with the left hand through a detestable opportunistic behavior; CSR does not mean providing benefits to a particular community at the expense of another community; CSR means achieving justice in rights. CSR means keeping away from opportunistic behavior. CSR means not to exploit legal gaps to achieve economic gains. CSR means not to deceive public opinion, even if it is legally permissible. Where data and information should be disclosed in accordance with transparency standards. CSR is a thought that embraces all lofty meanings that oppose all unethical behaviors and practices and tools that contribute to the spread of those behaviors and practices; CSR is not a way to export the failure of management in managing its resources to society or a means to reduce economic losses. For example, it is not a tool to reduce economic losses in inventory by donating obsolete inventory "obsolete stock" or inventory whose validity period is nearing completion, in order to achieve tax savings that contribute to reducing the amount of economic damage resulting from the obsolete inventory and the validity or expiration dates of the product " validity of inventory usage in the coming period."

\section{WHAT IS NEW ABOUT CORPORATE PHILANTHROPIC RESPONSIBILITY?}

One of the common mistakes in the field of CSR is that people are used to understanding CSR in the field of interaction with the community as donations to charities and nonprofit organizations without waiting for the restoration of those expenditures by the donor corporations or with some positive achievements "such as tax incentives." The content of the idea of corporate philanthropic responsibility means contributing to the achievement a real revolution in the field of economic development and infrastructure within society, the method used to achieve that end is not important, as long as it is legitimate. Loans are a type of financial contribution that corporations make to their communities in which they operate, which can be included in the list of corporate philanthropic responsibilities. Financial assistance in the form of loans contributes to creating a harmony between corporate economic responsibility (safeguarding the economic resources of the donor corporation) and corporate philanthropic responsibility (contribution to the creation of real economic development and infrastructure development in the communities in which they operate).

The content of the CSR idea is still under development. It does not mean stagnation but rather the search for the best trends that corporations can take in order to fulfill their social responsibility towards their communities. Accordingly, it is possible to say that governments and legislative authorities - in any country in the world, must look for the best ways to make corporations truly contribute to the development of their communities in which they operate and at the same time maintain their economic potential. This means the necessity to create a kind of harmony between the corporate economic responsibility and the corporate philanthropic responsibility. One of the common misconceptions about the concept of corporate social responsibility is to consider donations as the only evidence to prove that corporations interact with the issues and aspirations of the communities in which they operate. The interaction between corporations and the community can be in the form of loans rather than donations that weaken the economic capabilities of corporations. If this perception "scenario" happens which refers to adopting the idea of lending instead of the idea of giving or donation, it can be said that, there is a state of harmony between the corporate economic responsibility and the corporate philanthropic responsibility. Whereas the growth of the corporation's economy is the growth of the state economy or society. The content of the idea of CSR means the effective contribution of corporations to the creation of real economic development and the enhancement of infrastructure in the communities in which they operate, regardless of the method or approach taken to achieve this purpose. Adopting the idea of lending instead of the idea of giving or donation means commitment to CSR in a rational way. The new in the field of corporate philanthropic 
responsibility lies in changing the policy of interaction with society "transition from donation policy to lending policy." The new policy aims to create a kind of harmony between corporate philanthropic responsibility and corporate economic responsibility. This change should be supported by the development of income tax laws. Especially, in the area of tax treatment of corporate spending in the field of interaction with the aspirations of the community to support economic development and infrastructure.

\section{Advantages and Disadvantages of Tax Treatment Methods for Corporate Monetary and In- Kind Donations}

Through the researcher's deep understanding of the nature of these methods and his visualization of all the negative and positive effects that they can produce, a set of advantages and disadvantages can be devised for each method of tax treatment for monetary and in-kind donations.

It should be noted that, the evaluation results (for the five methods) may differ according to the following three variables: The deduction amount "tax exemption"; The value of the donation ;The method of tax treatment of corporate donations. As well as, the level of impact of the used method differs according to the following two variables: the deduction amount " tax exemption" ;The value of the donation. This study describes how to evaluate the methods used in the tax treatment of corporate donations, based on specific criteria.

FIRSTLY: Donations as if they are operating expenses: method of society's rights and then government's right (tax exemption in the sense of deduction).

When the value of tax incentives (value of the tax savings) increases, the value of the government's tax revenue decreases by the amount of these gains. Therefore, the level of gains and damages will depend on the amount of these incentives.

\section{The disadvantages of this method}

This method contributes to reducing state tax revenues; This method contributes to creating what can be called a mandatory" Compulsory" partnership between the government and the donor corporations; This method contributes to achieving the tax savings. This is incompatible with the content of the idea of CSR referred to above; This method does not contribute to the achievement of tax justice among corporations "donor and non-donor." It does not achieve fair economic growth for corporations. This method is unfair to shareholders, as it adversely affects shareholders' equity. By deducting the value of donations from the value of taxable income, the value of distributable income to shareholders will decrease. Compared with other treatment methods, this method may also contribute to a reduction in the market value of the shares of the donor corporations. Especially when the amount of the donation is large, and also in the absence of a role for competitive advantage; This method generates tax savings and therefore the value of donations does not represent real sacrifice incurred by corporations; This method is incompatible with the meanings and contents of the CSR. One of the most important of which is the realization "achievement" of justice in rights among all stakeholders. This method may be a gateway to pass many unethical practices and behaviors.

As for the advantages-for donor corporations: Donor companies can realize economic benefits (tax savings); Enhancing competitive advantage. This method is considered stimulating for corporations to continue their charitable activities in the communities in which they operate.

SECONDLY: Donations as if they are indirect taxes: method of society's rights and then government's rights (tax exemption in the sense of restoration" return").

In practice, this method is not used, but it remains one of the scenarios. 


\section{The Disadvantages of this Method}

This method contributes to reducing state tax revenues; This method may contribute to the atrophy and the disappearance of the idea of CSR or loss of the true meaning of the CSR in the field of interaction with the issues and aspirations of society. Donations will be refunded to the donor corporation as if those who incur those donations are the governments and not the corporations. As for the advantages, the only potential advantage is to enhance the donor corporation's competitive advantage.

The method of society's rights and then government's rights "tax exemption in the sense of deduction" is inconsistent with the content of the idea of CSR, for the following reasons:

According to the researcher's point of view, the accurate analysis of this method "tax exemption in the sense of deduction" conceals behind it a state of compulsory partnership.CSR is a commitment based on voluntarism in most of its areas. According to this method, donations are voluntarily incurred by corporations while the government is obligated by law to bear" incur" a portion of those donations (tax savings earned by donor corporations). The researcher believes that this method compels the government to contribute to these donations in a mandatory, nonvoluntary manner. The tax laws that permit this are in fact distorting the true meaning of CSR; The idea of CSR did not appear to exist for economic gain outside the competitive advantage, and it did not come into existence to promote opportunistic behavior and exploit legal loopholes. If this happens, the CSR will lose its true meaning and will deviate from its noble and lofty goals and motives. This method contributes to achieving the tax savings and economic gains-outside the competitive advantage, thus it is incompatible with the content of the CSR idea; CSR is the performance of activities and the achievement of goals in an ethical manner and behavior. The CSR should be above the level of suspicion and uncertainty.CSR as a modern idea is antagonistic to the opportunistic behavior. The CSR is not a means of exporting the administrative failure to other parties, and is not a means of reducing the economic losses of corporations through the exploitation of legal gaps. This method may be a means to achieve that. This method may be exploited by corporations to get rid of obsolete inventory or inventory whose validity period is nearing completion through the donation to government agencies and bodies or charities, not to interact with the issues and aspirations of the community, but to reduce the economic losses of those corporations; CSR is not a means of circumventing and deception. This method, in the absence of a comprehensive disclosure of donations "not to disclose the tax savings and real sacrifice "can contribute to misleading public opinion about those donations. This is contrary to the principle of transparency in the presentation of data and financial information; One of the contents of the CSR idea is to achieve justice in the field of the rights among all stakeholders. Adopting this method is unfair to the government. It contributes to reducing government revenues from taxes. As well as, this method does not contribute to the achievement of tax justice for donor corporations" especially when there is no market competition. "This method also does not achieve tax justice for investors in the donor and non-donor corporations" taxes on dividends.";The idea of CSR is to achieve the goals of the organization in an ethical behavior. It fights corruption. It is a tool to make corporations above all suspicions. It avoids adopting all means and factors by which unethical behavior can be practiced by bad management. This method may be an entryway through which many unethical behaviors can be passed on; CSR is an idea above all suspicions. It did not emerge to exist to be within the circle of suspicion and interpretation of intentions by the public and evaluators. The adoption of this method does not reflect the hidden intent behind the incurring of monetary and in kind donations by corporations; CSR does not mean to cause harm to any of the stakeholders.CSR does not mean support for a party and at the same time harming another party. According to this method, the aggrieved party is the government. This method contributes to the reduction of government revenues from taxes. 
Journal of Business School, vol.4, issue.3, pp.197-219

\section{THIRDLY: donations as if they are not granted: method of government's rights and then society's rights.}

\section{The disadvantages of this method}

This method does not achieve tax justice among corporations "especially in a non-competitive market situation." As well as, it is unfair to shareholders. This method may contribute to the emergence of so-called double taxation. Shareholders will incur such donations in addition to tax on distributions; This method does not generate any tax savings for the donor corporations. This may contribute to the reluctance of corporations to continue to make donations.

\section{Advantages of this method}

According to this method, donations cannot be used as a means of tax evasion. This method prevents the use of donations as a means to pass some unethical practices and opportunistic behaviors by corporations; This method has no effect on government tax revenues. This method does not generate the tax savings, which can contribute to reducing the amount of real sacrifice incurred by corporations; This method reflects the true intentions of corporations regarding contribution to the development of the communities in which they operate. The obligation of corporations to pay donations will reflect the optimum level of corporate dedication "sincere intentions" to fulfill their social responsibility toward their societies.

The method of government's rights and then society's rights is consistent with the content of the idea of CSR, but not ideally, for the following reasons:

This method will put corporate donations above the level of suspicions. The sincere intention of corporations to develop their communities and their serious commitment to their social responsibility in the societies in which they operate can be confirmed when this method is adopted by the legislative bodies and applied by the tax authority, and with the continuation of corporations in the donation activities. This situation will reflect the desired ideal position of CSR in the community; This method is consistent with the content of the CSR idea with regard to the achievement of justice in rights. Justice here is in the sense not to harm a party in return for the benefit of another party. Government revenues should not be affected by donations paid by corporations. In light of the terrible population explosion and the increase in the burden of government, this method will contribute to support the government in meeting its obligations towards its society without any financial bottlenecks due to the decrease in revenue from direct taxes as a result of these unexpected donations. As the continuation of corporations to make donations despite the application of this method by the tax authority in the State reflects an idealism degree about CSR within the community. Here, it should be noted that both society and government are independent parties in the stakeholder group and both represent an area of CSR areas. Based on this it can be said that, the method of tax treatment that favors a party at the expense of another party will be a breach of CSR's content that calls for the achievement of justice in the distribution of rights; This method does not achieve justice among corporations, and among investors in corporations (because there are some corporations incur those donations and others do not incur; CSR means transparency and non-circumvention and this method is fully consistent with this matter. The tax treatment of monetary and in kind donations by using this method will reflect the real sacrifices incurred by corporations towards both the society -through donations in the context of interaction with its issues and aspirations "without achieving any economic gains outside the framework of competitive advantage," and the government through taxes paid without any deductions for those contributions. This method contributes to the promotion of noble and great principles of CSR. This method is not conducive to the practice of unethical behaviors. 


\section{FOURTHLY: Donations as if they are loans method of government's rights and then corporation's rights in government's rights.}

This method contributes to reducing the impact of legal imbalances in the field of rights to the lowest possible level, unlike the previous methods; This method contributes to strengthening of economic development and infrastructure in the country in a more effective and clear way "under the assumption that, donations will be made to accomplish those purposes, according to the vision on which this method depends" ; This method also contributes to increasing the rate of flow of corporate donations to the public treasury of the state and the growing of the social role of corporations; This method safeguards the content of the idea of CSR and contributes to the achievement of an unparalleled harmony between corporate philanthropic responsibility and corporate economic responsibility (by preserving the economic resources of the corporation and contributing to the development of the society in which it operates, at the same time); This method contributes to the development of the concept of corporate philanthropic responsibility by moving from the traditional role(donation approach) to the modern role(lending approach).

As for the disadvantages, if the texts of this law and its articles are not selected in a professional manner and defined in a smart way and with the influx of large amounts of corporate donations to the State Treasury and the government is committed to returning "pay" installments of those donations to donor corporations. It will be expected that the government will be subjected to financial bottlenecks in future periods due to the decrease in the amount of tax revenues. This problem can be avoided by issuing an executive regulation that includes all the precautionary measures.

The method of government's rights and then corporation's rights in government's rights is consistent with the content of the idea of CSR. It contributes to the development of the concept of corporate philanthropic responsibility.

Under the assumption that, donations will be provided to promote economic development and infrastructure in the country-according to the vision on which this method depends, this method will reflect the desired social role of corporations. This method will reflect the real social interaction of corporations with the communities in which they operate. This method safeguards the content of the idea of CSR and contributes to the achievement of an unparalleled harmony between corporate philanthropic responsibility and corporate economic responsibility (by preserving the economic resources of the corporation and contributing to the development of the society in which it operates, at the same time);This method contributes to the development of the concept of corporate philanthropic responsibility by moving from the traditional role(donation approach) to the modern role (lending approach).

FIFTHLY: Donations as if they are joint cost: method of" government's rights and then part of society's rights in government's rights: a part of donations as if it is indirect taxes (tax exemption in the sense of restoration), or a part of donations as if it is operating expenses (tax exemption in the sense of deduction).

This method has the same advantages and disadvantages as the first and second methods, in addition to the following two disadvantages: There is a difficulty in apportioning the joint cost to determine the share of competitive advantage and the share of social benefits; The share of the social benefit in the joint cost does not represent the true cost that produced that benefit. Also, the share of the competitive advantage in the joint cost does not represent the true cost that enhanced that advantage. 
Journal of Business School, vol.4, issue.3, pp.197-219

\section{THE BILL"PRELIMINARY DRAFT LAW"}

\section{Corporation as if it is a loaner for government: Optimal tax treatment of corporate monetary and in-kind donations}

This method" law" is suitable for countries that suffer from problems and near-recurrent deficits in the public spending budget from year to year. Good governments are the ones that should avoid borrowing from foreign countries or the World Bank or raise fees and taxes, and then a disruption "confusion" of economic life (a disruption of livelihoods) and adopt the idea of relying on corporate donations to cover their public expenses.

Through the previous presentation, it is clear that the method of government's rights and then corporation's rights in government's rights "donations as if they are loans" is much more advantageous than the other four methods. Given the importance of this method, the researcher proposed a bill dealing with the tax treatment of monetary and in-kind donations, which can achieve the following benefits and advantages: Reducing economic damage to donor corporations" impact on market value of shares" ; The protection of the content of idea of CSR by considering that donations are as subsidies to the community" as a matter of lending, not granting" -use the money for a certain period, "great harmony between corporate economic responsibility and corporate philanthropic responsibility" ;Encouragement of taxpayers to make more donations; To come close to achieving justice in rights between governments and communities looking for greater prosperity; Approaching" getting closer" to a large extent of the case of achieving full tax justice among investors in donor corporations; Eliminating all negative phenomena associated with donation operations through the subjection of those donations to strict control; The Prevention of double taxation.

\section{THE BILL" PRELIMINARY DRAFT LAW"}

\section{Corporation as if it is a loaner for government "donations as if they are loans"}

Optimal tax treatment of corporate monetary and in-kind donations.

The lower number of installments will motivate corporations to pay more donations

Article (1): Corporate monetary and in-kind donations should be in areas that are subject to government spending in the state such as "supporting government institutions, programs of economic development and infrastructure of the state. These donations are voluntary, and are not compulsory; Article (2): Donations are refunded by deducting them from income tax payable to the tax authority, and not from any other government financial resources; Article (3): Corporate monetary and in-kind donations are under the supervision and control of government in the country. The Ministry of Finance is an intermediary between donor corporations and governmental institutions, organizations and other ministries that benefit from these donations; Article (4): The Ministry of Finance in the State must adhere to the expenditure of voluntary contributions in the fields specified by the donor corporations. The Ministry of Finance is not allowed to spend voluntary funds "cash and non- cash donations" for purposes not specified by the donor corporations; Article (5): The value of donations is deducted from income tax payable to the tax authority in equal installments over five years. This means ignoring the contributions when determining the value of taxable income; Article (6): The support of charities and nonprofit organizations is through corporate employees. With the mediation of the Ministry of Finance in the State concerning the receipt and distribution of the values of donations to charities and non-profit organizations, according to a specific policy. The donation is $\$ 3$ per month from the salary of each employee works for the company. Corporate responsibility is to transfer those amounts to the Ministry of Finance monthly. These donations are mandatory; Article (7):Not to include staff contributions in the list of expenses to be deducted from the revenues of the 
corporation "ignore those contributions when determining the taxable income."; Article (8):Ignoring any donations made by corporations, contrary to what is specified in Article (1) when determining the value of the income tax payable or when determining the value of donations that must be deducted from income tax payable to the tax authority; Article (9):After 5 years, the corporation will have recovered the value of those donations. Provided that the income of the donor corporation in those years shall not be less than the income in the year of donation "installments are not deducted in the year in which income is less than income in the year of donation."Ignoring this issue may confuse the government when estimating its tax revenues in future periods. This is what can be called a corporation as if it is a loaner for government; Article (10): All donation activities must be supported by official documents; Article (11): In-kind donations must be estimated at the cost of manufacture or purchase; Article (12): Obsolete inventory" goods" and fixed assets should be estimated at market value; Article (13): Donations made by the donor corporations are in two areas: In the field of promotion of economic development and infrastructure; In the field of spending on government institutions, bodies and organizations. With the need to create a kind of the balance between the two areas.

\section{Advantages of this method:}

Adoption of this law will contribute to achieving the following benefits:

In the field of economic development and infrastructure enhancement. The adoption of this law will motivate corporations to make more donations that will contribute to enhancing the economic development and infrastructure in the country; This law will prevent the compulsory partnership and double taxation; To promote the idea of social solidarity within societies. Donations are made by corporations, employees and workers in the country, but in different fields. Building contemporary societies is a collective responsibility; All donation activities are under government supervision and control. All donations will be subject to government control. With this procedure, all the negative aspects associated with the donation activities will disappear; This law will prevent unethical practices and behaviors associated with charitable activities such as tax evasion, money laundering, etc.; This law preserves the content of the idea of CSR. This law does not undermine the freedom of corporations in the field of donations, but regulates its procedures and directs them on the right track. Here, CSR means contributing to economic construction of societies, as well as maintaining the economic capabilities of corporations "commitment to economic responsibility as well as a commitment to philanthropic responsibility towards the communities in which they operate" by supporting economic development and strengthening infrastructure for them. The retrieval of donations does not imply prejudice to the essence of the idea of CSR. This goal is fully consistent with the content of the idea of CSR and its noble principles; Developing the concept of corporate philanthropic responsibility. The proposed bill will contribute to the development of the concept of Corporate Philanthropic Responsibility" changing the philosophy of donations through the shift from the policy of giving to the policy of lending.";There is no significant impact on the government's annual revenues from taxes. If this law is adopted, there is no significant impact on the government's annual revenue from taxes. Given that corporate donations-which are considered as loans in this law, will not be deducted from tax income payable to the tax authority at once time but over five years. Thus, the reduction in government's annual revenue from taxes will be little; This law achieves justice in rights among government, donor corporations and society. The three parties will benefit from this law. According to this law, there is no losing party. Communities will benefit from the gains that will be made by the economic development programs and plans, and the public services that will be provided by the state's advanced infrastructure, which will be financed through corporate donations. Governments will receive financial support from donor corporations to perform their functions and complete of their 
development plans and programs .Donor corporations will recover their funds after five years and therefore they will not lose anything; Reducing economic damage to donor corporations" impact on market value of shares."Adoption of this law does not result in achieving tax savings. Not deducting donations from taxable income as in other laws and deducting them from income tax payable to the tax authority - in accordance with this law, will reduce economic damage to donor corporations" impact on the market value of shares" unlike other tax treatments that result in tax savings that vary their values among donor corporations, according to the amount of the donation value, and the consequent difference in the value of the true sacrifice among the donor corporations." Note: Donations are considered as accounts receivable, that are not involved in determining the result of the activity"; Positive change in government spending policies. This law will encourage corporations to donate in the areas defined by this law, and governments will receive huge amounts of money from donor corporations. This huge amount of money will make the governments rearrange their policies in the field of government spending and adjust their budgets, especially in the areas of economic development and strengthening the infrastructure in those countries; Advance knowledge "foreknowledge \prior knowledge." This law will help the government to know the amount of decline in its tax revenues in future periods(by knowing the amount of annual installments to be returned to the donor corporations and quarterly activity results for those corporations,) and then take all early measures to address any deficit in the budgets.

\section{The disadvantage of this method, and how to avoid it}

In case of adoption and application of this law "method of government's rights and then corporation's rights in government's rights" there will be concerns about the decline in government revenues from taxes in future periods because of the accumulation of contributionsresulting from corporations continuing to make donations, under the policy of returning these contributions to the donor corporations(returning the installments to the donor corporations).This decrease results in the possibility that the government will be unable to meet its obligations in the area of government spending. Factors that may contribute to the occurrence this problem are: A significant reduction in revenues of donor corporations in future periods; Lack of reasonable balance between donations in the field of promotion of economic development and infrastructure and donations in the field of spending on government institutions, bodies and organizations. The researcher believes that articles 13;9;4;3;2 will contribute to preventing this problem. (in the event that donor corporations continue to make donations from one year to another, there will be concerns about the decline in state revenues from taxes in the future due to the increase of installments value. Here it can be said that, the revenues and expenses of corporations as a whole are not fixed, that is, a decrease in the tax revenues of certain corporations may be offset by an increase in other corporations. Any increase in the value of taxable income for the base year (compared to the base year) must be used to pay the installments to prevent the accumulation of installments value. In the event that the value of the taxable income does not exceed the base year, the annual installment value must not exceed the value calculated in the base year).

In the case of growth of the revenues of the donor corporations from year to year there will be no significant impact on the state revenues from taxes. But in the worst circumstances, in order to avoid this problem, the following guidelines must be observed: Relocation of the surplus in the budget for the past year as a reserve in the current year's budget to face any decrease in the state revenues from taxes; Formation of a reserve in the budget to meet any reduction in the state revenues from taxes; Donations "loans" must be authorized by the government and in areas that need financial support through the contribution of corporations; The government should determine the value of the donation "loan" that the donor corporations should make. It is 
desirable that the values should be small and equal to avoid the negative impact of a decrease in state revenues from taxes as a result of the decline in the revenues of those donor corporations in the future; Failure to accept any donation requests from corporations regarding the financing of a specific project in the event of obtaining sufficient funding for its completion by corporations; It is preferable to use the quarterly system in determining the income of the donor corporations after deducting the installments of the donations that should be returned to those donor corporations. To avoid any financial bottlenecks and try to address them early; The rate of donation in the field of spending on government institutions, bodies and organizations should be higher than the donation in the field of promotion of economic development and infrastructure. That rate depends on the number of corporations in the state.

\section{RECOMMENDATIONS}

The researcher recommends the need to adopt the method of government's rights and then corporation's rights in government's rights due to the many advantages. This method contributes to achieving the following benefits: Promoting economic development and infrastructure in the country; Creating a kind of harmony between corporate philanthropic responsibility and corporate economic responsibility (creating an effective social role for corporations by developing a real and productive interaction between the corporations and their communities); Minimize legal imbalances in the fields of tax justice and justice in the rights to the lowest level; Preventing unethical conduct.

\section{CONCLUSION}

Allowing taxable income to be reduced with a portion of donations may motivate donor corporations to continue making more donations, but it suffers from some failures related to "undesirable economic impacts; legal imbalances; violation of the content of the CSR idea, "which makes this method not ideal, which can be avoided by using the method of government's rights and then corporation's rights in government's rights, "donations as if they are loans." More scientific research is expected in this area, as well as serious interest in the content of this study by legislative bodies.

\section{REFERENCES}

Al Rai Newspaper . ( 2011 ,18November).The private sector calls for legislation to stimulate the adoption of the idea of CSR . Retrieved from: http:// alrai.com/ article/ $681515 \mathrm{html}$

Avi-Yonah, R,( 2014 ). Just Say No: Corporate Taxation and CSR, Public Law and Legal Theory Paper series no. 402 University of Michigan. Retrieved from: /// C:/Users/ ECSK/Downloads / SSRN-id2423045.pdf

Carroll, Archie B. (2016). Carroll's pyramid of CSR: taking another look. International Journal of Corporate Social Responsibility. 1:3.pp1-8. Retrieved from: https://jcsr .springer open .com /track/pdf/ 10.1186 /s 40991-016-0004-6

Dattani, P., Still, A., and Pota, V. (2015). Business backs education: Creating a baseline for corporate CSR spend on global education initiatives. Business backs education. Retrieved September 23, 2016. Retrieved from: http://businessbackseducation.org/ research/

Grigore, Georgeta( 2010 ).Ethical and Philanthropic Responsibilities in Practice. Annals of the University of Petroşani, Economics, 10(3), 2010, 167-174.Retrieved from: https:// www.upet.ro/annals/ economics/pdf /2010/20100317.pdf

John, Rob , Chia, Audrey and Ito, Ken.( 2017 ). Corporate Philanthropy in Asia Innovations that Unlock the Resources of Business for the Common Good. Entrepreneurial Social Finance in Asia: Working Paper No. 5 Asia centre for social entrepreneurship \& philanthropy. NUS. 
Retrieved from: https://bschool.nus.edu .sg/Portals/ 0/images/ACSEP/Publications/acsepworking-paper-no5-ebook .pdf.

Lordemus, Samuel ( 2013 ). Evaluating the efficiency of the tax incentives toward corporate philanthropy. Master's thesis. Paris School of Economics. The University of Paris 1.Panthéon Sorbonne.

Madrakhimova, Firuza S.(2013). Corporate Philanthropy. Global Conference On Business And Finance Proceedings . Volume 8 .Number 2.pp125-132. Retrieved from: http://old.uona .edu/ Uo NA/files/ literature/3231 .2634_ISSN-1941-9589-V8-N2-2013_c.pdf

Man ,Theresa L.M. ( September 18,2006 ). Corporate Giving : A Tax Perspective. Paper available Retrieved from: www .carters .ca/pub/ article/charity /2007/tlm_ corpgiving.pdf

Ministry of Finance \General Secretariat of Taxation "Sultanate of Oman"(2017).Amendment to the Tax Code" under Royal Decree No. 9/2017.Retrieved from: https:// tms.taxoman .gov. om/ porta /ar/web/taxportal/news/-/asset_publisher /V05zDAqSo Mrz / content /id/83184

Mihaljevic, Marija and Tokic, Ivana( 2015). Ethics and Philanthropy in the Field of Corporate Social Responsibility Pyramid. Interdisciplinary Management Research, JosipJurajStrossmayer University of Osijek, Faculty of Economics, Croatia, vol. 11, pp 799807.

Perry, Suzanne ( 2006 ). Giving by Companies Rose 14\% Last Year, Study Finds" The Chronicle of Philanthropy, June 15, 2006; Fleishman-Hillard Research and National Consumers League: "Rethinking Corporate Social Responsibility" (Fleishman-Hillard Research and National Consumers League, 2006) (Retrieved from: http:// www .csrresults .com).

Saleh,Younis A. Battal (2020).Advantages And Disadvantages Of The Four Methods Of Tax Treatment Of Corporate Monetary And In-Kind Donations: A Theoretical Study Of Intellectual Enrichment In The Fields Of Taxation And Corporate Philanthropic Responsibility .JOBMER .4 (1) 74-139.

Sudaress (2013).Donations for Taxes. Retrieved from: https://www .sudaress.com /alintibaha /2 9759.

Svernlöv, Carl ( 2016 ). Corporate Social Responsibility and Corporate Taxation. Retrieved from: https:// www.svensktnaringsliv.se/migration_catalog/Rapporter_och_opinionsmaterial / Rapporter / corporate _ social _report_webbpdf_ 666655.html/BINARY /Corporate_ Social_report_webb.pdf 